\title{
Demand Response for Selected Animal Products in Ibadan
}

\author{
Adeniyi, O. A. ${ }^{1}$, Kayode, O. A. ${ }^{2}$, Alabi, A. A. ${ }^{2}$ and Orimafo, P. K. ${ }^{2}$ \\ ${ }^{1}$ Department of Agricultural Economics, Ladoke Akintola University of Technology, P. M. B 4000, Ogbomoso, \\ Nigeria. \\ ${ }^{2}$ Department of Agricultural Extension and Rural Development, Ladoke Akintola University of Technology, \\ P. M. B 4000, Ogbomoso, Nigeria.
}

\begin{abstract}
The high increase in population rate and the inadequate incentives for the production of beef and fish threatens their demand. Therefore, this study evaluated demand elasticity for animal products, in the rural areas of Ibadan, Nigeria. A multistage sampling technique was used for the selection of 120 respondents. Primary data were subjected to Descriptive Statistics and the Linear Approximate of Almost Ideal Demand System (LA/AIDS) Model. This study revealed an average household size of 7 persons and the mean age of household heads was 51 years old. The mean amount spent on the animal products monthly were 1807 and 1651: 08 for beef and fish respectively. The respondents who demanded for the animal products were 69.2\% and $90 \%$ for beef and fish respectively. The income elasticity were 3331 and 0.0106 for beef and fish respectively: thus, beef was a luxury but fish was a necessity. The result of the cross elasticity were 0.059 and 0.084 for beef and fish respectively: therefore, they were substitutes. Policy makers should therefore promote intensive management of cattle and fish to enhance their production, so that they could be affordable by both the privileged and the less privileged households.
\end{abstract}

Key words: Animal products, budget share, elasticity

\section{Introduction}

Animal products supply protein, fat and mineral to the body. They are important as source of income to the farmers and the government. Animal products were estimated to be consumed per capita-per day at less than 10.0g compared with the recommended 35.0g by World Health Organization in Nigeria (Okojie, 1999). Beef form an integral part of the family diet in Nigeria, it is served as table meal: and it is important in improving human health status. Fish are a vital source of nutrition for the world's poor. 400 million poor people in Africa and Asia rely on fish for more than half of their daily protein intake (Warren, 2005). Moreover, the fish sub sector in Nigeria accounts for about $40 \%$ of animal protein in the diet, and it contributed $4.74 \%$ of the agricultural share of the nations GDP in 2003 (Ojo and Fagbenro, 2003). Globally the demand for fish continues to climb, especially in developed nations: which in 2004 imported 33 million tonnes of fish: worth over US $\$ 61$ billion: which was $81 \%$ of all fish imports, in that year, in value terms (FAO, 2006). Nigeria is characterized by deprivation and abject poverty: in the midst of enormous natural and human resources (Alamu, Abiodun and Miller, 2004). Therefore, enhancing production of animal products could improve the living condition of the populace.

The objectives of this study are to:

i. Examine socio-economic characteristics of household in the study area.

ii. Ascertain demand status for selected animal products in the study area.

iii. Estimate own price, cross price and income elasticity of demand for selected animal products in the study area.

\section{Methodology}

Study area: The study was conducted in Ibadan, the capital of Oyo -State: which is in the southwestern Nigeria. Ibadan is the largest city in West Africa, with land size covering an area of $240 \mathrm{~km}^{2}$ and has an estimated population of $2,881,416$ by the 2006 population census (National Population census, 2006). The city is located on geographic grid reference longitude $3^{\circ} 5 \mathrm{E}$ latitude $7^{\circ} 20 \mathrm{~N}$ (Adedokun, Adeyemo, Adeleye and Yusuf, 2008). This location confers on the city the equatorial climatic conditions. There are two distinct seasons: the wet and dry season. The wet season is the period of rainfall, which is between April and October characterized by double maxima distribution in the Southern part, a result of the influence of the South Western monsoon wind on the atmosphere. The dry season covers between November and March and it is characterized by hot weather. The hot weather is dry and accompanied by dust storms due to the effect of North-East trade winds between December and early January (Hand book on Agricultural Activities in Oyo State, 2001).

Ibadan is situated at an average height of $200 \mathrm{~m}$ above sea level, drained by three major river basins (Ogunpa, Ona and Ogbere) and surrounded by secondary rainforest as well as a savanna. Spatially, it sprawls 
over a radius of 12-15 km and experiences a mainly tropical climate with an estimated annual rainfall of about $1250 \mathrm{~mm}$ (UNCHS/UNEP, 1997). Average daily temperature ranges between $25^{\circ} \mathrm{C}$ and $35^{\circ} \mathrm{C}$. The climate in the city favours the cultivation of crops like maize, yam, cassava, millet, rice, plantain, cocoa tree, palm tree and cashew. It consists of 11 Local Government Areas. It is an important commercial centre and it comprises of different socio-economic and cultural backgrounds.

\section{Sampling procedure and sample size}

A multistage sampling technique was used for the selection of the household heads. The first stage involved the purposive sampling of 3 Local Government Areas from the rural areas of Ibadan, namely Egbeda, Oluyole and Ona-ara. The second stage involved random sampling of wards from each of the 3 Local Government Areas. The third stage was the systematic sampling of household heads. For the purpose of analysis, 120 respondents were interviewed.

\section{Source of data analysis}

The data used were mainly primary: these were obtained through the use of a well-structured questionnaire and interview schedule. This was employed to make enquiries on socio-economic characteristics of the household.

\section{Analytical tools and procedure}

The tools and procedure that were employed elucidated the objective of the study: this includes the following.

\section{Descriptive Statistics}

Descriptive Statistics were employed. They are the mean, percentages and frequency distribution. These were used as tools to describe preferential characteristics and socioeconomic information of the individual and household selected for the survey.

\section{Linear approximate of almost ideal demand system model}

The Linear Approximate AIDS (LA/AIDS) that uses Stone (expenditure) share weighted price instead of the nonlinear general price index of full AIDS model is used to estimate the demand system (Deaton and Muellbauer, 1980). The relationship of consumers' income and prices of different items to the portion of total expenditure can be expressed as:

$\mathrm{W}_{\mathrm{i}}=\mathrm{a}_{\mathrm{i}}+\mathrm{b}_{\mathrm{i}} \ln \left(\mathrm{M} / \mathrm{P}^{*}\right)+\sum \mathrm{Y}_{\mathrm{ij}} \ln \mathrm{P}_{\mathrm{j}}+\mathrm{EV}+\mathrm{U}_{\mathrm{i}}$

For; $\mathrm{i}=1, \ldots \ldots \ldots \ldots \ldots \ldots \ldots, 2$ (animal products) items.

$\mathrm{j}=1$ (animal products) groups.

Where;

$\mathrm{W}_{\mathrm{i}}=$ budget share of item $\mathrm{i}$,

$a_{i}=\quad$ average value of the budget share of item $i$ in the absence of price and income effects,

$b_{i}=\quad$ effects of real income on the budget share of item $i$,

$\mathrm{Y}_{\mathrm{ij}}=$ effects of the prices of items in group $\mathrm{j}$ on the budget share of item $\mathrm{i}$,

$\mathrm{M}=\quad$ total expenditure on the group of items being analyzed,

$\mathrm{P}_{\mathrm{i}}=\quad$ weighted average price of items in group $\mathrm{j}$,

$\mathrm{V}=\quad$ vector of other independent variables,

$\mathrm{E}=\quad$ coefficient of other independent variable,

$\mathrm{P}^{*}=\quad$ price index approximated by Stone price index,

$\mathrm{U}=$ error term

Given equation (1), any AIDS model that uses Stone's price index, which is called the Linear Approximate AIDS (Alston and Green, 1990).

Therefore in equation 1

$\ln \mathrm{P}=\quad \mathrm{W}_{\mathrm{j}} \ln \mathrm{P}_{\mathrm{j}}$.

Where:

$\mathrm{W}_{\mathrm{j}}=$ the budget share of $\mathrm{j}$ group,

$\mathrm{P}_{\mathrm{j}}=\quad$ the average price (expenditure) of $\mathrm{j}$ group

$\mathrm{M} / \mathrm{P} \quad$ could be defined as a proxy for real income.

Thus, equation (1) can be expressed as:

$\mathrm{W}_{\mathrm{i}}=\mathrm{a}_{\mathrm{i}}+\mathrm{b}_{\mathrm{i}} \operatorname{logm}+\sum \mathrm{Y}_{\mathrm{ij}} \log \mathrm{P}_{\mathrm{i}}+\mathrm{EV}+\mathrm{U}$.

For; $\mathrm{i}=1, \ldots \ldots \ldots \ldots \ldots \ldots \ldots, 2$ (animal products) items.

$\mathrm{j}=1$ (animal products) groups.

$\mathrm{M}=\mathrm{M} / \mathrm{P}$, the proxy for the income

Theoretical inconsistencies could be avoided by placing the following restrictions on the AIDS model:

i. $\quad \sum \mathrm{Y}_{\mathrm{ij}}=\mathrm{O}$; this is known as the homogeneity restriction, and

ii. $\quad$ from equation (4), $\sum a_{i}=1$ and $\sum b_{i}=O$; these are known as the addivity restrictions.

Moreover, income elasticity and own price elasticity were computed from LA/AIDS model by using the following formulae (Olayemi and Olayide, 1981; Umo,1994). 
Income elasticity $\left(\mathrm{e}_{\mathrm{ij}}\right)=\frac{\partial w_{i}}{\partial Y_{i j}} \bullet \frac{Y_{i j}}{w_{i}}$

Where;

$\frac{\partial w_{i}}{\partial Y_{i j}}$ (First partial derivatives of $\mathrm{Y}_{\mathrm{ij}}$ with respect to $\mathrm{w}_{\mathrm{i}}$ )

$\mathrm{Y}_{\mathrm{ij}}=$ Geometric mean of income of the household (total monetary contribution to household expenditures)

$\mathrm{w}_{\mathrm{i}}=$ Geometric mean of budget share (dependent variable)

$\partial w_{i}=$ Partial change in budget share of animal products.

$\partial Y_{i j}=$ Partial change in income of the household (total monetary contribution to household expenditure)

Own price elasticity $\left(\mathrm{e}_{\mathrm{ij}}\right)=\frac{\partial w_{i}}{\partial P_{i j}} \bullet \frac{P_{i j}}{w_{i}}$

Where $\frac{\partial w_{i}}{\partial P_{i j}}$ (First partial derivatives of $\mathrm{P}_{\mathrm{ij}}$ with respect to $\mathrm{w}_{\mathrm{i}}$ )

$\mathrm{P}_{\mathrm{ij}}=$ Geometric mean of own price of animal products.

$\mathrm{w}_{\mathrm{i}}=$ Geometric mean of budget share (dependent variable)

$\partial w_{i}=$ Partial change in budget share of animal products.

$\partial P_{i j}=$ Partial change in own price of animal products.

Cross price elasticity $\left(\mathrm{e}_{\mathrm{ij}}\right)=$

$\frac{\partial w_{i}}{\partial K_{i j}} \bullet \frac{K_{i j}}{w_{i}}$

Where;

$\frac{\partial w_{i}}{\partial K_{i j}}$ (First partial derivatives of $\mathrm{K}_{\mathrm{ij}}$ with respect to $\mathrm{w}_{\mathrm{i}}$ )

$\mathrm{K}_{\mathrm{ij}}=$ Geometric mean of price of each of the other animal products.

$\mathrm{w}_{\mathrm{i}}=$ Geometric mean of the budget share (dependent variable)

$\partial w_{i}=$ Partial change in budget share of animal products

$\partial K_{i j}=$ Partial change in price of each of the other animal products

\section{Results}

Socio economic characteristics of the entire household members

Table 1revealed the definition of independent variable used in LA/AIDS model. Table 2 revealed the socioeconomic characteristics of the household head (respondents).

Age: The mean age of household heads was 51 years.

Educational status: Household heads that had no formal education were $1.70 \%$ of the respondents: while those that had formal education were $98.3 \%$ of the respondents of the study. Amidst this: $22.5 \%, 51.2 \%$ and $24.2 \%$ had primary, secondary and tertiary education respectively: These were deduced from the number of years they spent at school.

Monthly income: The household heads with a monthly income of less than 25,001 were over $84 \%$ of the respondents. The mean monthly income of the household heads in this study was $\$ 17,314$.

Major occupation: The majority of the household heads interviewed were artisans: these accounted for $57.4 \%$ of the respondents: this consist of mechanics, bricklayer, tailors, to mention a few. However, those whose major occupation was trading were only $18.4 \%$ : while $24.2 \%$ of the respondents were civil servants.

Secondary occupation: About $55 \%$ of the household head's had no secondary. Artisan makes $37.2 \%$ of the respondents.

Sex: Majority $(99.2 \%)$ of the household heads were males: while the remaining $0.80 \%$ were females. The female household heads in this study were widows.

In table 3, the socio economic characteristics of the entire household members were stated. 
Household size: The household with a number of (between 2 -6) $56.4 \%$ had the highest percentage. The average household size was seven.

Total monthly monetary contribution to household expenditure: Total monthly monetary contribution to household expenditure is the summation of monthly income of household heads, monthly income of wives and total monetary contribution of other household members to household expenditure. The mean of the total monthly monetary contribution to household expenditure was $\$ 26,122.500$.. Maximum total monetary contribution to household expenditure was $\$ 160,000$ while the minimum total monetary contribution to household expenditure was $\$ 1200$.

Demand status of animal products

Table 4 shows the demand status of animal products.

Beef: About sixty-nine percent of the respondents demanded for beef: while $30.8 \%$ did not demand for it.

Fish: Ninety percent of the household demanded for fish: while10\% had no preference for fish.

\section{Amount spent on animal products}

Table 5 revealed monthly price of animal products.

Beef: About $69 \%$ of the household demanded for beef. Majority of the household spent between 1,201 to 2,200 on it monthly. This amounts to $40.8 \%$ of the household. The mean price was 1,807 per month.

Fish: Ninety percent of the household demanded for fish. Expenditure on fish was up to above 4500 per month: while the mean price was 1651 monthly.

\section{Elasticity for animal products}

Table 6 revealed the elasticity for animal products

\section{Income elasticity of animal products}

The income elasticity of beef and fish were 3311 and 0.0105 respectively.

Own price elasticity of animal products

The own price elasticity of beef was 0.134 . The result of this study revealed that fish had own price elasticity of -0.0482 .

\section{Cross price elasticity of animal products}

The cross price elasticity was shown for animal products.

The budget share of beef (BS BEEF) had cross price elasticity with the price of fish. The cross price elasticity was 0.0592 . The price of beef (PR_FISH) had cross price elasticity with respect to the budget share of fish (BS_FISH). The value of the cross price elasticity of PR_BEEF with respect to BS_FISH was 0.0837 .

\section{Discussions}

The household heads in the study were grown-up adults, who could still contribute immensely to the economy. Their high literacy level could encourage the acceptability of innovation and help in the choice of the best animal products. The respondents were majorly low income earners. Income plays a vital role in the expenditure level of an individual. The income of an individual tends to dictate his level of demand or change in taste for alternative goods (Amao, Oluwatayo and Osuntope, 2006). Therefore, majority of the household could not been able to afford animal products due the expensiveness. The respondents engage themselves in productive ventures.

The result of this study that, household size of 7 was the average household size in Nigeria has been confirmed (Bongaarts,2001). This result revealed the inadequacy of the effort of the USAID (United States Agency for International Development), PPFN (Planned Parenthood Federation of Nigeria) and the Nigeria government towards proper family planning in Nigeria. The mean of the total monthly monetary contribution to household expenditure was $\$ 26,122.500$. This is not economically advantageous for optimum livelihood of the average family size of 7. Maximum total monetary contribution to household expenditure of $\$ 160,000$ versus the minimum total monetary contribution to household expenditure of $\$ 1200$ : indicated that there was very large gap between the poor and the rich. It was confirmed that, income inequalities had increased in Nigeria (Tonny, 2007). The demand for beef and fish were very high. Beef and fish took a large part of the household expenditure.

Elasticity refers to the responsiveness of a dependent variable to a given change in an independent variable [14]. For the purpose of this study, elasticity can therefore be referred as the responsiveness of the budget share of animal products to changes in any of the variables that affect demand. Income elasticity, own price elasticity and cross price elasticity of animal products were computed and discussed in this section.

Income elasticity measures the degree of responsiveness of household demand for animal products with respect to one percent change in household income (Umo, 1994). The income elasticity of beef was 3311 this was an indication that beef was a luxury good this may be because of the expensiveness of the beef. The income elasticity for fish was 0.0105 . This was an indication that fish was a necessity. 
Own price elasticity can be defined as the responsiveness of the budget share of a product to a change in price of the same product (Umo, 1994). The own price elasticity of beef was 0.134 . The own price elasticity for beef was positive and less than 1 . The demand here was own price inelastic. This implies that, a change in the price of beef brought about a less than proportional change in their share of budget. The result of this study revealed that fish had own price elasticity of -0.0482 . This suggested that a $1 \%$ change in the price of fish evoked $0.04 \%$ demand of fish in the opposite direction. Cross price elasticity is the responsiveness of budget share of a commodity to the changes in the price of another commodity (Umo, 1994). The sign of cross price elasticity indicate whether the combination was complementary to or substitute for the other (Tanko, 1994).

The budget share of beef (BS_BEEF) had cross price elasticity with the price of fish. The cross price elasticity was 0.0592 . The positive sign suggest that, fish and BS_BEEF be for substitutes for the other. It also implies that, a $1 \%$ change in the price of the fish evoked $0.05 \%$ change in BS_BEEF.

The price of beef (PR_FISH) had cross price elasticity with respect to the budget share of fish (BS_FISH). The value of the cross price elasticity of PR_BEEF with respect to BS_FISH was 0.0837. The positive sign suggests that, the commodities could be substitutes for the other. It also, indicates that, a $1 \%$ change in the price of beef brought about $0.08 \%$ change in the budget share of fish (BS_FISH).

\section{Conclusions And Recommendations}

This study shows that fish was a necessity while beef was a luxury in Ibadan. It is therefore recommended that, policy makers enhance fish production in this part of Nigeria. This will meet fish demand among deprived households. In addition, the problem associated with the responsiveness of rural households to changes in prices of animal products could be minimized through policies that promote stability in the provision of affordable animal products.

Table 1: Definition Of Independent Variable Used In La/Aids Model

\begin{tabular}{lll}
\hline $\begin{array}{l}\text { Symbols } \\
\text { in } \\
\text { equation }\end{array}$ & $\begin{array}{l}\text { Variable name and } \\
\text { Description }\end{array}$ & Types of variable \\
\hline HD_AGE & Age of household head & Continuous variable \\
HD_EDU & Number of years in school by the household head & Continuous variable \\
SIZE & Household size & Continuous variable \\
TOTAL_INCOM & Total household expenditure (\#) & Continuous variable \\
PR_BEEF & Expenditure on/Price of beef (\#) & Continuous variable \\
PR_FISH & Expenditure on /Price of fish (\#) & Continuous variable \\
REAL_BEEF & Real Expenditure on beef $(\#)$ & Continuous variable \\
REAL_FISH & Real Expenditure on fish $(\#)$ & Continuous variable \\
\hline
\end{tabular}

Table 2: Socio Economic Characteristics Of Household Heads

\begin{tabular}{|c|c|c|}
\hline Socio Economic Characteristics & Frequency & Percentage \\
\hline \multicolumn{3}{|l|}{ Age (years) } \\
\hline$<30$ & 0 & 0.00 \\
\hline $31-50$ & 60 & 49.6 \\
\hline $51-70$ & 42 & 34 \\
\hline$>70$ & 18 & 16.4 \\
\hline \multicolumn{3}{|l|}{ Mean $=51$ years } \\
\hline \multicolumn{3}{|c|}{$\begin{array}{l}\text { Number of years spent at school } \\
\text { (years) }\end{array}$} \\
\hline No schooling & 2 & 1.70 \\
\hline$<1$ & 0 & 0.00 \\
\hline $1-6$ & 27 & 22.5 \\
\hline $7-12$ & 62 & 51.2 \\
\hline $13-18$ & 25 & 20.9 \\
\hline$>18$ & 4 & 3.30 \\
\hline Total household mo & & \\
\hline \multicolumn{3}{|c|}{ expenditure/Monthly income (\#) } \\
\hline$\leq 5000$ & 7 & 6.10 \\
\hline $5001-15000$ & 73 & 60.4 \\
\hline $15001-25000$ & 21 & 17.8 \\
\hline $25001-35000$ & 6 & 4.80 \\
\hline $35001-45000$ & 3 & 2.40 \\
\hline$>45000$ & 10 & 8.50 \\
\hline \multirow{2}{*}{\multicolumn{3}{|c|}{$\begin{array}{l}\text { Minimum }=1000, \text { Mean }=17,314, \\
\text { Maximum }=150,000\end{array}$}} \\
\hline & & \\
\hline \multicolumn{3}{|l|}{ Major occupation } \\
\hline Civil service & 29 & 24.2 \\
\hline Trading & 23 & 18.4 \\
\hline Artisan & 68 & 57.4 \\
\hline Secondary occupation & & \\
\hline
\end{tabular}




\begin{tabular}{lll}
\hline No minor occupation & 66 & 54.8 \\
Civil servant & 4 & 3.20 \\
Trading & 6 & 4.80 \\
Artisan & 44 & 37.2 \\
Sex & & \\
Male & 119 & 99.2 \\
Female & 1 & 0.80 \\
\hline
\end{tabular}

Source: Field survey, 2012.

Table 3: Socio Economic Characteristics Of The Entire Household Members

\begin{tabular}{lll}
\hline Socio Economic Characteristics & Frequency & Percentage \\
\hline Household size & 0 & \\
2 & 68 & 0.0 \\
$2-6$ & 41 & 56.4 \\
$7-11$ & 8 & 34.8 \\
$12-16$ & 3 & 6.40 \\
$>16$ & & 2.40 \\
Mean = 7, Maximum =19 & & \\
Total monthly monetary & contribution & \\
household expenditure (N) & 0 & \\
$<1000$ & 70 & 0.00 \\
$1000-20000$ & 31 & 58 \\
$21000-40000$ & 9 & 26.8 \\
$41000-60000$ & 5 & 7.20 \\
$61000-80000$ & 4 & 3.20 \\
$81000-100000$ & 1 & 0.80 \\
$>100000$ & Minimum $=1200$ & \\
Mean $=26122.500$, & & \\
Maximum $=160000$ & & \\
\hline
\end{tabular}

Source: Field survey, 2012.

Table 4: Demand Status Of Animal Products

\begin{tabular}{lll}
\hline Demand status/Variables & Frequency & Percentage \\
\hline Beef & & \\
Demand & 83 & 69.2 \\
No demand & 37 & 30.8 \\
Fish & & \\
Demand & 108 & 90 \\
No demand & 12 & 10 \\
\hline
\end{tabular}

Source: Field survey, 2012.

Table 5: Amount Spent Monthly On Animal Products

\begin{tabular}{lll}
\hline Price (\$) & Frequency & Percentage \\
\hline Beef & & \\
No demand/No price & 29 & 22.2 \\
$\leq 200$ & 1 & 0.80 \\
$201-1200$ & 18 & 15.6 \\
$1201-2200$ & 45 & 40.8 \\
$2201-3200$ & 11 & 8.30 \\
$3201-4200$ & 10 & 8 \\
$>4200$ & 6 & 4.30 \\
Mean $=1807$ & & \\
Fish & 12 & 10 \\
No price/No demand & 10 & 8.30 \\
$\leq 500$ & 50 & 31.9 \\
$501-1500$ & 33 & 28.3 \\
$1501-2500$ & 8 & 6.70 \\
$2501-3500$ & 3 & 2.50 \\
$3501-4500$ & 4 & 2.30 \\
$>4500$ & & \\
Mean $=1651: 08$ & & \\
\hline
\end{tabular}

Source: Field survey, 2012. 
Table 6: Elasticity For Animal Products

\begin{tabular}{lll}
\hline Income Elasticity & Variable & Elasticity \\
\hline & Beef & $3311^{* *}$ \\
Own Price Elasticity & Fish & $0.0105^{* *}$ \\
& PR_BEEF & $0.134^{*}$ \\
Cross Price Elasticity & PR_FISH & $-0.0482^{* * *}$ \\
& BS_BEEF & 0.0592 (PR_FISH) \\
& BS_FISH & 0.0837 (PR_BEEF) \\
\hline
\end{tabular}

$* * * 1 \%$ level of significance, $* * 5 \%$ level of significance, $* 10 \%$ level of significance

Source: Computed from LA/AIDS estimates of the field survey, 2012.

\section{References}

[1]. O. A. Adedokun, O. K. Adeyemo, E. Adeleye, and R. K. Yusuf, Seasonal Limnological Variation and Nutrient Load of the River System in Ibadan Metropolis, Nigeria. European Journal of Scientific Research ISSN 1450-216X 2008; 23: 98-108 (C) EuroJournals Publishing, Inc. 2008. http://www.eurojournals.com/ejsr.htm

[2]. S. O. Alamu, J. A. Abiodun, and J. W. Miller, Food Security and Poverty Alleviation Under the National Special Programmed for Food Security: A Preliminary Socio Economic Assessment of Yamma Lake, Kebbi State. In: P.A Araoye (Ed). Proceedings of 19th Fisheries Society of Nigeria Conference 2004: 149-162.

[3]. J. M. Alston, J. M. and R. Green, Elasticities in AIDS Model. American Journal of Agricultural Economics, 1990 72 (2), pp. $442-$ 445 .

[4]. J. O. Amao, I. B. Oluwatayo, and F. K. Osuntope, Economics of Fish Demands in

[5]. Lagos - State, Nigeria. Journal of Human Ecol., 2006, 19 (1), pp. 25 - 30

[6]. J. Bongaarts, Household Size and Composition in the Developing World. Policy

[7]. Research Working Paper, 2001, No 144. 1 - 38 Pp. Deaton, and J. Muellbauer, An Almost Ideal Demand System. American Economic

[8]. Review, 1980, 70, pp. 312-326.

[9]. FAO, The State of World Aquaculture 2006. A Paper Presented to Delegates from More than 50 Countries at the Biennial Meeting of the FAO Sub-Committee on Aquaculture. New Delhi 4-8 September. FAO News Room, 2006.

[10]. Handbook on Agricultural Activities in Oyo - State, About Oyo - State. A handbook prepared by Department of Planning, Research and Statistics of the Ministry of Agriculture, Oyo State, 2001.

[11]. National Population Census (NPC), Details of the Break down of National and State Provisional Total 2006 Census, Lagos: Federal Government Nigeria, 2006.

[12]. J. K. Olayemi, and S. O. Olayide, Elements of Applied Econometrics. First Edition, Ibadan: Card, 1981.

[13]. S. O. Ojo, and O. A. Fagbenro, Empirical analysis of factors influencing demand for fish in Nigeria. International Institute of Fisheries Economics and Trade, Corvallis, Oregon, (USA), 2004.

[14]. J. A. Okojie, The role of government and universities of agriculture in improving animal production and consumption in Nigeria. Tropicana Journal of Animal Sciences 1999; 2 (2): 1 - 7

[15]. M. Tonny, M. Sub - Saharan Income Inequalities Widen. Business Report on Line Edition.

[16]. Powered by IOL, 2007.

[17]. J. U. Umo, Practial Microeconomic Analysis in African Context. Lagos: Net link Research Consult Ltd, 1994.

[18]. UNCHS, (Habitat)/UNEP, City Experiences and International Support. 1997; 2: 67-70

[19]. E. Warren, How do we ensure fish for all? Address Delivered by the Director of Environment, the World Bank at the NEPAD fish for all summit in Abuja Nigeria, on August 25, 2005 